\title{
O CÂNTICO DA TERRA ${ }^{1}$
}

Eu sou a terra, eu sou a vida.

Do meu barro primeiro veio o homem.

De mim veio a mulher e veio o amor.

Veio a árvore, veio a fonte.

Vem o fruto e vem a flor.

Eu sou a fonte original de toda vida.

Sou o chão que se prende à tua casa.

Sou a telha da coberta de teu lar.

A mina constante de teu poço.

Sou a espiga generosa de teu gado

e certeza tranqüila ao teu esforço.

Sou a razão de tua vida.

De mim vieste pela mão do Criador,

e a mim tu voltarás no fim da lida.

Só em mim acharás descanso e Paz.

Eu sou a grande Mãe Universal.

Tua filha, tua noiva e desposada.

A mulher e o ventre que fecundas.

Sou a gleba, a gestação, eu sou o amor.

A ti, ó lavrador, tudo quanto é meu.

Teu arado, tua foice, teu machado.

$\mathrm{O}$ berço pequenino de teu filho.

$\mathrm{O}$ algodão de tua veste

e o pão de tua casa.

\section{A AUTORA}

\section{Cora Coralina}

Pseudônimo de Ana Lins de Guimarães Peixoto Bretas (18891985), também chamada Aninha da Ponte da Lapa. Trabalhou como doceira, na cozinha da Casa da Ponte, em seu Estado natal, Goiás, produzindo seus versos ao pé do fogo. Publicou seu primeiro livro aos 75 anos de idade. Freqüentou somente o curso primário e recebeu o título Honoris Causa pela Universidade Federal de Goiás de doutora feita pela vida.
E um dia bem distante a mim tu voltarás.

E no canteiro materno de meu seio tranqüilo dormirás.

Plantemos a roça.

Lavremos a gleba.

Cuidemos do ninho, do gado e da tulha.

Fartura teremos

e donos de sítio

felizes seremos. 